\title{
JAOS

\section{Effect of hydroalcoholic extract of Myracrodruon urundeuva All. and Qualea grandiflora Mart. leaves on the viability and activity of microcosm biofilm and on enamel demineralization}

\section{Abstract}

Juliana Gonçalves PIRES ${ }^{1}$

Aline Silva BRAGA ${ }^{1}$

Flaviana Bombarda de ANDRADE ${ }^{2}$

Luiz Leonardo SALDANHA ${ }^{3}$

Anne Lígia DOKKEDAL ${ }^{3}$

Rodrigo Cardoso de OLIVEIRA ${ }^{1}$

Ana Carolina MAGALHÃES
Submitted: August 15, 2018 Modification: October 30, 2018 Accepted: November 28, 2018

Corresponding address: Ana Carolina Magalhães Departamento de Ciências Biológicas - Faculdade de Odontologia de Bauru - Universidade de São Paulo. Al. Dr. Octávio Pinheiro Brisolla, 9-75 17012-901 - Bauru - SP - Brasil. Phone/Fax. + 551432358497 e-mail: acm@fob.usp.br
Objectives: The aim of this study was to assess the effect of Myracrodruon urundeuva All. and Qualea grandiflora Mart. leaves hydroalcoholic extracts on viability and metabolism of a microcosm biofilm and on enamel demineralization prevention. Methodology: Microcosm biofilm was produced on bovine enamel using inoculum from pooled human saliva mixed with McBain saliva, under $0.2 \%$ sucrose exposure, for 14 days. The biofilm was daily-treated with the extracts for $1 \mathrm{~min}$. At the end, it was analyzed with respect to viability by fluorescence, CFU counting and extracellular polysaccharides (phenol-sulphuric acid colorimetric assay) and lactic acid (enzymatic assay) production. The demineralization was measured by TMR. The data were compared using ANOVA or Kruskal-Wallis $(p<0.05)$. Results: $M$. urundeuva All. at 100, 10 and $0.1 \mu \mathrm{g} / \mathrm{mL}$ and $Q$. grandiflora Mart. at 100 and $0.1 \mu \mathrm{g} / \mathrm{mL}$ reduced biofilm viability similarly to positive control (chlorhexidine) and significantly more than the negative-vehicle control (35\% ethanol). $M$. urundeuva at 1000,100 and $0.1 \mu \mathrm{g} / \mathrm{mL}$ were able to reduce both lactobacilli and mutans streptococci CFU counting, while Q. grandiflora (1000 and 1.0 $\mu \mathrm{g} / \mathrm{mL}$ ) significantly reduced mutans streptococci CFU counting. On the other hand, the natural extracts were unable to significantly reduce extracellular polysaccharides and lactic acid productions neither the development of enamel carious lesions. Conclusions: The extracts showed antimicrobial properties on microcosm biofilm, however, they had no effect on biofilm metabolism and caries protection.

Keywords: Antimicrobial agents. Dental caries. Biofilms. Plant extracts. Phytotherapy.
'Universidade de São Paulo, Faculdade de Odontologia de Bauru, Departamento de Ciências Biológicas, Bauru, São Paulo, Brasil.

'Universidade de São Paulo, Faculdade de Odontologia de Bauru, Departamento de Dentística, Endodontia e Materiais Odontológicos, Bauru, São Paulo, Brasil.

${ }^{3}$ Universidade Estadual Paulista (UNESP), Faculdade de Ciências, Departamento de Ciências Biológicas, Bauru, São Paulo, Brasil. 


\section{Introduction}

Dental caries involves dental biofilm rich in acidogenic and aciduric bacteria such as Streptococcus mutans, Streptococcus sobrinus, Lactobacillus sp., Veillonella, Actinomyces, bifidobacteria and fungi, ${ }^{1}$ which are metabolically active under frequent sugar exposure, producing acids that induce tooth demineralization. ${ }^{2}$ Mechanical disorganization of dental biofilm by brushing and rationing sugar consumption are key strategies to prevent the disease. In addition, conventional antimicrobial oral mouthrinses can be recommended for patients at high-risk level. ${ }^{3}$ However, their antimicrobial properties may not reflect into an anti-caries effect and, additionally, may induce some side-effects such as taste alteration, tooth staining and mucosa desquamation. 4,5 Therefore, scientists are directing attention to folk medicine in order to find alternative antimicrobial agents against oral diseases as dental caries. ${ }^{6}$

Brazil is the country harboring the highest plant diversity, allocated mainly in Cerrado and the Atlantic Forest. ${ }^{7}$ Myracrodruon urundeuva All. (Anacardiaceae) and Qualea grandiflora Mart. (Vochysiaceae) are examples of plants from Brazilian Cerrado.

M. urundeuva has antimicrobial action, $, 8,9$ including action against mutans streptococci, ${ }^{10}$ as well as analgesic, hepatoprotective, antidiarrheal, colonic anastomotic wound healing and anti-ulcerogenic effects. ${ }^{11} Q$. grandiflora exhibits anti-ulcerogenic action in the ethanolic extract of its bark. ${ }^{12}$ Besides, this extract has an antioxidant effect, ${ }^{13}$ analgesic and anticonvulsive potential ${ }^{14}$ and antibacterial action. ${ }^{15}$

Regarding dental caries, a previous study tested the effect of aqueous extracts of $M$. urundeuva on mutans streptococci counts and on dental enamel micro-hardness of rats submitted to cariogenic challenges. The extract promoted significant reduction of mutans streptococci counts as well as enamel demineralization. ${ }^{16}$

Recently, our research group showed that both hydroalcoholic extracts of $M$. urundeuva and Q. grandiflora leaves (isolated or combined) had antimicrobial action; however, they did not prevent enamel caries formation under the mutans streptococci biofilm model. ${ }^{17}$ Therefore, there is no consensus about the anti-caries action of the extracts. Furthermore, there is no information about their mechanism of action under more complex biofilm models (such as multispecies or microcosm biofilm).

Considering the need for alternatives to prevent dental caries in specific populations that are under unfavorable socioeconomic conditions, ${ }^{18}$ the aim of our study was to evaluate the effect of hydroalcoholic extracts of $M$. urundeuva and $Q$. grandiflora leaves on the viability and metabolism of a microcosm biofilm and on the prevention of enamel demineralization.

\section{Methodology}

\section{Saliva collection}

This study was approved by the local Ethics Committee (CEEA 43948115.2.0000.5417). After consent, the saliva pool collected from 2 healthy donors who followed the inclusion criteria previously described by Souza, et al. ${ }^{19}$ (2018) was mixed with glycerol and frozen.

\section{Plant material preparation}

Leaf samples of $M$. urundeuva and $Q$. grandiflora were collected in October 2013 at the Jardim Botânico Municipal de Bauru (Bauru, Brazil), (22²0'41.4"S - 49 $\left.01^{\prime} 45.1^{\prime \prime} \mathrm{W}\right)$. Exsiccates were deposited in the Herbarium of UNESP under code numbers HRCB59831 and UNBA6034. The collections have authorization issued by SISBIO under code number 39825-1. The leaves' extracts were prepared as described by Machado, et al. ${ }^{20}(2016)$.

\section{Tooth sample preparation and treatment groups}

Three hundred and six enamel samples ( $4 \mathrm{~mm} \times 4$ $\mathrm{mm}$ ) were prepared from bovine teeth, following the study by Braga, Pires and Magalhães ${ }^{5}$ (2018). Sample size was calculated based on a previous study. ${ }^{17}$ The samples were sterilized using ethylene oxide [gas exposure time $\left(30 \% \mathrm{ETO} / 70 \% \mathrm{CO}_{2}\right)$ for $4 \mathrm{~h}$ under a pressure of $0.5 \pm 0.1 \mathrm{kgF} / \mathrm{cm}^{2}$ ].

The enamel samples were randomly divided into treatment groups by using their average roughness-Ra means (Ra: $0.153 \pm 0.037 \mu \mathrm{m}$ ) as criteria, presented as follows: PerioGard ${ }^{\circledR}$ with alcohol $(0.12 \%$ chlorhexidine digluconate, Colgate; São Bernardo do Campo, São Paulo, Brazil) - Positive control (pH 5.0); 35\% ethanol -Negative/Vehicle control ( $\mathrm{pH} 5.7)$; hydroalcoholic extracts from the leaves of $M$. urundeuva at $0.1(\mathrm{pH}$ $5.7) ; 1.0(\mathrm{pH} \mathrm{5.8)} ; 10(\mathrm{pH} \mathrm{5.2)} ; 100(\mathrm{pH} \mathrm{5.2)}$ and 
$1000 \mu \mathrm{g} / \mathrm{mL}(\mathrm{pH} 4.8)$ and $Q$. grandiflora at $0.1(\mathrm{pH}$ 5.3); $1.0(\mathrm{pH} \mathrm{5.4);} 10(\mathrm{pH} \mathrm{5.1);} 100(\mathrm{pH} \mathrm{4.9)}$ and $1000 \mu \mathrm{g} / \mathrm{mL}(\mathrm{pH} 4.5)$. All extract solutions contained $35 \%$ alcohol as solvent.

\section{Microcosm biofilm formation and treatments}

The human saliva was defrosted and mixed with McBain saliva ${ }^{21}$ in a proportion of $1: 50$. The microcosm biofilm was produced as described in previous studies. 5,19 The samples were placed in a 24-well plate and the solution containing human saliva and McBain saliva was added to each well ( $v=1.5 \mathrm{~mL} /$ well), which was incubated at $5 \% \mathrm{CO}_{2}$ and $37^{\circ} \mathrm{C}$ for the first $8 \mathrm{~h}$. Thereafter, the samples were washed with PBS and exposed to fresh McBain saliva with $0.2 \%$ sucrose and incubated until completing the $1^{\text {st }}$ day, at the same conditions.

From the $2^{\text {nd }}$ to the $14^{\text {th }}$ day, the samples were treated once a day with natural agents or controls for $1 \mathrm{~min}(1 \mathrm{~mL} /$ well $)$ at room temperature. Afterwards, the samples were washed using PBS, and fresh McBain saliva containing $0.2 \%$ sucrose was added. The microplates were then incubated at $37^{\circ} \mathrm{C}$ and $5 \% \mathrm{CO}_{2} \cdot{ }^{22}$

\section{Biofilm viability analysis}

The biofilm was stained using the Kit Live \& Dead $^{\circledR}$ cells viability assay (Thermo Fisher Scientific; Waltham, Massachusetts, USA). ${ }^{17}$ The biofilm was examined using confocal laser scanning microscope-CLSM (Leica TCS SPE; Mannheim, Baden-Württemberg, Germany) and Leica Application Suite-Advanced Fluorescence software (LAS AF; Mannheim, Baden-Württemberg, Germany). Three images $\left(275 \mu \mathrm{m}^{2}\right)$ were captured and analyzed using the BioImage L 2.0 application software to quantify the live and dead bacteria (\%).

\section{Microorganism viability analysis}

For colony-forming unit CFU counting, $100 \mu \mathrm{l}$ of the bacterial suspension was diluted to $10^{-4}$ and spread on petri dishes ( $25 \mu \mathrm{l} / \mathrm{dish}$ ) containing two different types of agar: A) SB-20M ${ }^{23}$ for determination of mutans streptococci (S. mutans and S. sobrinus); and B) Rogosa (Kasvi; Curitiba, Paraná, Brazil) supplemented with $0.13 \%$ glacial acetic acid to assess the number of lactobacilli. ${ }^{24}$ The plates were then incubated at $5 \% \mathrm{CO}_{2}$ and $37^{\circ} \mathrm{C}$. After $48 \mathrm{~h}$, the CFU numbers were counted and transformed in $\log _{10} \mathrm{CFU} / \mathrm{mL}$.

\section{Metabolism analysis}

\section{a) Lactic acid production}

For this assay, only the highest and lowest concentrations of each extract were tested. Lactate concentrations were evidenced by means of the enzymatic method (lactic dehydrogenase method, Boehringer; Mannheim, Baden-Württemberg, Germany) according to the manufacturer's instruction. ${ }^{25}$ Absorbance was measured at $340 \mathrm{~nm}$ using a microplate reader (Fluorstar Optima- BMG Labtech; Ortenberg, Baden-Württemberg, Germany). The values were expressed as mmol lactate/L. ${ }^{5}$

\section{b) Extracellular polysaccharides - EPS quantification}

The insoluble and soluble EPS were quantified as previously performed. ${ }^{5}$ Total carbohydrates were measured using the phenol-sulphuric acid colorimetric assay under absorbance of $490 \mathrm{~nm}$ using a microplate reader (Fluorstar Optima- BMG Labtech; Ortenberg, Baden-Württemberg, Germany). ${ }^{26}$ The values for both EPS were expressed as $\mu \mathrm{g}$ EPS/mg (biofilm). ${ }^{5}$

\section{Transverse microradiography (TMR)}

Enamel slices with $80-100 \mu \mathrm{m}$ of thickness were fixed in a sample-holder together with an aluminum calibration step wedge with 14 steps. Microradiographs were taken using an x-ray generator (Softex; Tokyo, Honshu, Japan) on the glass plates. ${ }^{17}$ The glass plates were developed and analyzed using a transmitted light microscope fitted with a 20x objective (Zeiss; Oberkochen, Baden-Württemberg, Germany), a CCD camera (Canon; Tokyo, Honshu, Japan), and a computer containing software from the Inspektor Research System bv (Amsterdam, North Holland, The Netherlands). The cavitation depth (CD, $\mu \mathrm{m})$ was calculated as previously described. ${ }^{17,19}$

\section{Statistical analysis}

All experiments were performed in biological triplicate (except the lactate assay, in duplicate) with three data points for each replicate. Data were statistically analyzed using the application software Graph Pad Instat for Windows (GraphPad Software; San Diego, California, USA). Normal distribution and homogeneity were checked using Kolmogorov \& Smirnov and Bartlett's tests, respectively. The \% live and dead microorganisms were compared using ANOVA and Tukey-Kramer test. For the remaining analyses, Kruskal-Wallis followed by Dunn test was applied. The level of significance was set at $5 \%$. 


\section{Results}

\section{Bacterial viability}

Hydroalcoholic extracts of $M$. urundeuva at 100 $\mu \mathrm{g} / \mathrm{mL}(62.14 \%), 10 \mu \mathrm{g} / \mathrm{mL}(74.59 \%)$ and $0.1 \mu \mathrm{g} / \mathrm{mL}$ (59.81\%) and Q. grandiflora at $100 \mu \mathrm{g} / \mathrm{mL}(67.19 \%)$ and $1 \mu \mathrm{g} / \mathrm{mL}$ (64.50\%) presented mean percentage of dead cells similar to the positive control (chlorhexidine, $48.21 \%)$, and significantly higher than the negative control group (35\% ethanol, 33.79\%). The other experimental groups did not differ between themselves and positive and negative controls ( $p>0.05$, Figures 1 and 2 ). Figure 1 shows the percentage of viable microorganisms from each treatment's group. Figure 2 shows CLSM pictures of a representative biofilm sample from the most effective antimicrobial concentrations of the tested extracts.

\section{Microorganism viability}

Table 1 shows the CFU counting results. With respect to lactobacilli, only M. urundeuva at 1000,100 and 0.1 $\mu \mathrm{g} / \mathrm{mL}$ were able to reduce the CFU counting similarly to positive control and significantly more compared to negative control. M. urundeuva at similar concentrations had the same effect on mutans streptococci. Despite having no effect on lactobacilli, Q. grandiflora at 1000 and $0.1 \mu \mathrm{g} / \mathrm{mL}$ significantly reduced the number of mutans streptococci compared to negative control. Chlorhexidine significantly reduced CFU counting for both microorganisms compared to negative control.

\section{Metabolism analysis}

a) Lactic acid production

None of the extracts was able to significantly reduce lactic acid production compared to negative control; however, chlorhexidine significantly differed from negative control (Figure 3).

\section{b) EPS quantification}

Table 2 shows that none of the extracts was able to significantly reduce EPS production compared to the negative control, while chlorhexidine significantly reduced soluble EPS compared to negative control.

\section{TMR}

Enamel cavitation was seen in all groups with different cavitation depth values as shown in Figures 4 and 5 . None of the extracts was able to reduce cavitation depth, while chlorhexidine significantly reduced cavitation depth compared to the negative control (Figure 4). Figure 5 shows TMR pictures of a representative enamel sample from each treatment's group.

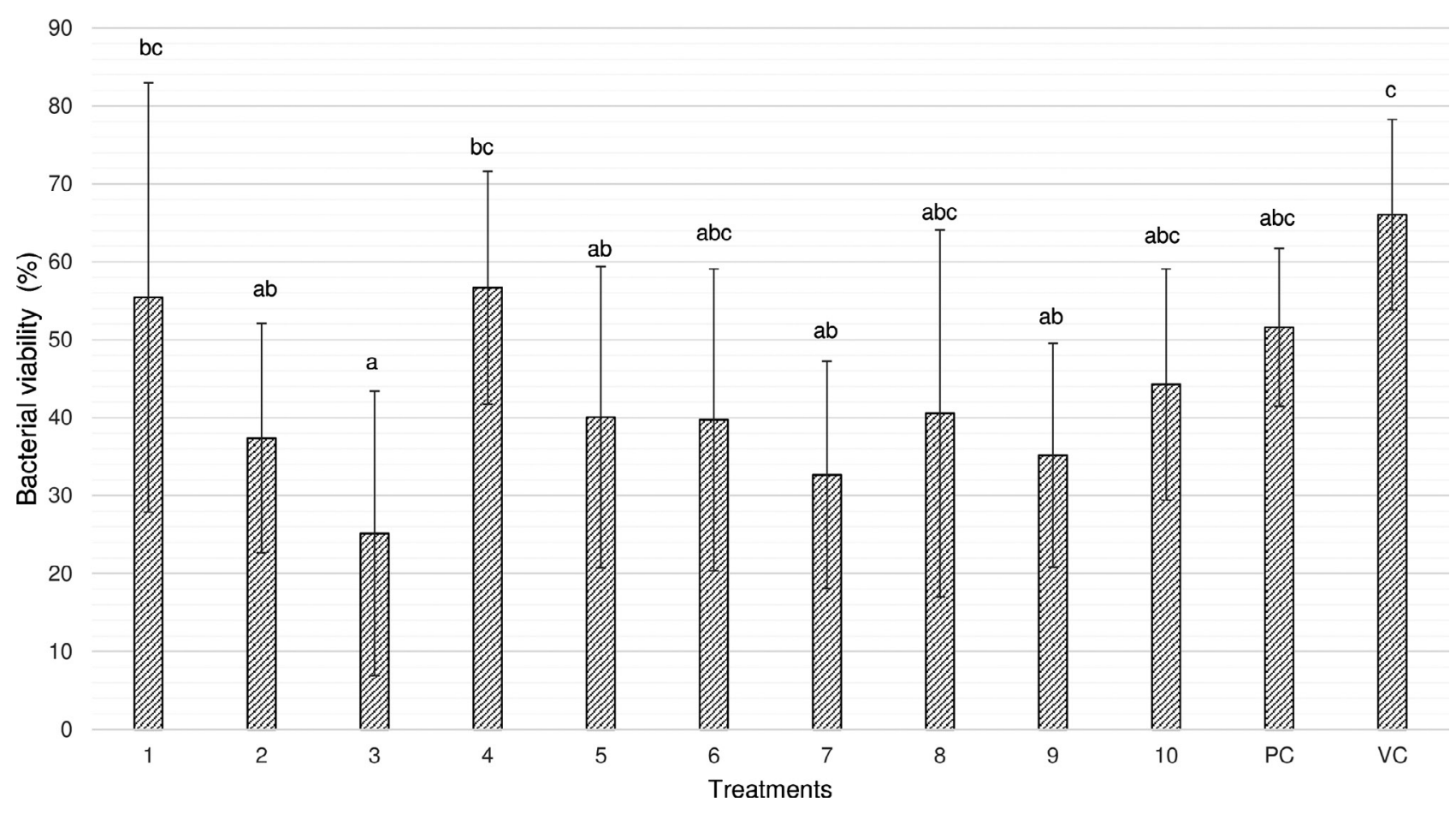

1- 5: M. urundeuva from 1000 to $0.1 \mu \mathrm{g} / \mathrm{mL}$ respectively; $6-10:$ Q. grandiflora from 1000 to $0.1 \mu \mathrm{g} / \mathrm{mL}$ respectively; PC: Positive control (Chlorhexidine, PerioGard $^{\circledR}$ ); VC: Vehicle (negative) control. Different letters show significant differences between treatments (ANOVA/ Tukey-Kramer, $p<0.0001)$

Figure 1- Mean \pm SD of the percentage (\%) of live microorganisms (viability assay using CLSM) from microcosm biofilm treated with hydroalcoholic extracts of $M$. urundeuva All. and Q. grandiflora Mart. leaves 

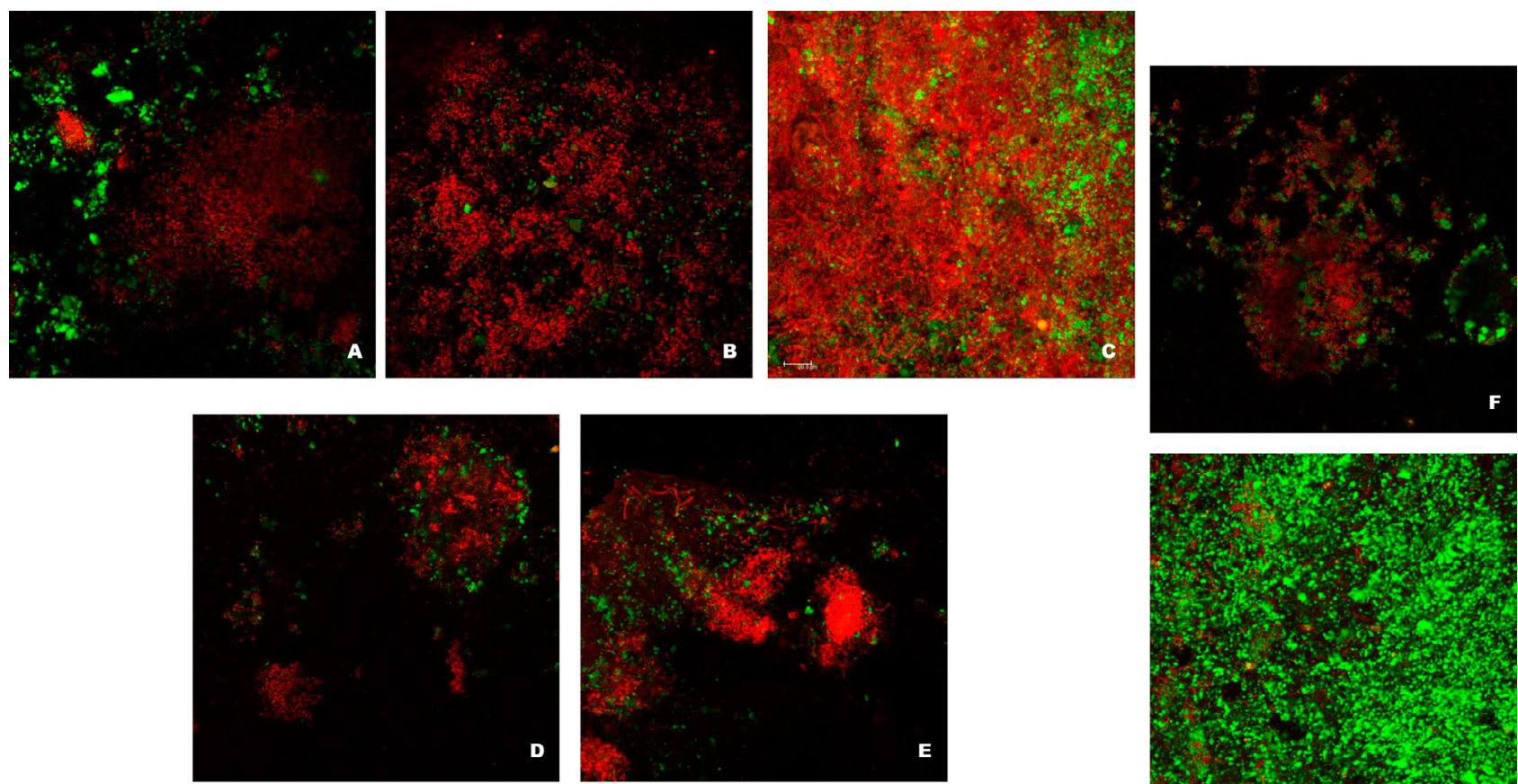

Figure 2- Representative image of the CLSM analysis from the groups: A-C) $M$. urundeuva at 100,10 and $0.1 \mu \mathrm{g} / \mathrm{mL}$, respectively; D-E) Q. grandiflora at 100 and $1 \mu \mathrm{g} / \mathrm{mL}$, respectively; F) Positive control (chlorhexidine, PerioGard ${ }^{\circledR}$ ); G) Vehicle (negative) control

Table 1- Median (interquartile interval) of CFU counting $\left(\log _{10} \mathrm{CFU} / \mathrm{mL}\right)$ for lactobacilli and mutans streptococci

\begin{tabular}{lll}
\hline \multicolumn{1}{c}{ Treatments } & lactobacilli & mutans streptococci \\
\hline 35\% Alcohol (vehicle/negative control) & $7.34(0.62)^{\mathrm{c}}$ & $7.60(0.61)^{\mathrm{c}}$ \\
\hline Chlorhexidine (positive control) & $6.72(1.09)^{\mathrm{ab}}$ & $6.64(1.44)^{\mathrm{ab}}$ \\
\hline M. urundeuva $1000 \mu \mathrm{g} / \mathrm{ml}$ & $6.81(0.54)^{\mathrm{a}}$ & $6.75(0.53)^{\mathrm{ab}}$ \\
M. urundeuva $100 \mu \mathrm{g} / \mathrm{ml}$ & $6.78(0.61)^{\mathrm{ab}}$ & $6.79(0.90)^{\mathrm{ab}}$ \\
M. urundeuva $10 \mu \mathrm{g} / \mathrm{ml}$ & $7.02(0.60)^{\mathrm{abc}}$ & $6.79(0.59)^{\mathrm{abc}}$ \\
M. urundeuva $1.0 \mu \mathrm{g} / \mathrm{ml}$ & $7.51(0.40)^{\mathrm{bc}}$ & $7.45(0.75)^{\mathrm{bc}}$ \\
M. urundeuva $0.1 \mu \mathrm{g} / \mathrm{ml}$ & $6.78(0.89)^{\mathrm{a}}$ & $6.25(0.54)^{\mathrm{a}}$ \\
Q. grandiflora $1000 \mu \mathrm{g} / \mathrm{ml}$ & $7.19(0.15)^{\mathrm{abc}}$ & $6.86(0.97)^{\mathrm{ab}}$ \\
Q. grandiflora $100 \mu \mathrm{g} / \mathrm{ml}$ & $7.43(0.56)^{\mathrm{bc}}$ & $7.57(1.06)^{\mathrm{c}}$ \\
Q. grandiflora $10 \mu \mathrm{g} / \mathrm{ml}$ & $6.98(0.52)^{\mathrm{abc}}$ & $7.02(1.15)^{\mathrm{abc}}$ \\
Q. grandiflora $1.0 \mu \mathrm{g} / \mathrm{ml}$ & $7.15(0.64)^{\mathrm{abc}}$ & $7.16(0.78)^{\mathrm{bc}}$ \\
Q. grandiflora $0.1 \mu \mathrm{g} / \mathrm{ml}$ & $6.88(0.69)^{\mathrm{abc}}$ & $6.81(0.51)^{\mathrm{ab}}$ \\
\hline
\end{tabular}

${ }^{*}$ Different superscript letters at the same column show significant differences between treatments (Kruskal-Wallis/Dunn: $p<0.0001$ for both)

\section{Discussion}

The use of plant extracts is a common practice in worldwide medicine, since phytotherapy is considered low cost and widely accessible. ${ }^{7}$ Brazil is one of the countries with the greatest biodiversity, ${ }^{7,27}$ a fact which in turn has stimulated the use of different types of plants for prevention and treatment of oral diseases based on their antimicrobial properties. ${ }^{7-10,15,17}$

The experimental model for studying the effect of plants on dental caries prevention must include assays that are capable of showing both 1) antimicrobial properties and mechanism of action (such as viability, EPS and lactic acid assays) and 2) the anti-caries effect (TMR), since one is not synonym to the other. Some known antimicrobial agents have no anti-caries potential, ${ }^{5}$ contraindicating their use for preventing the disease. Accordingly, we have chosen a microcosm biofilm model produced on enamel that is able to simulate the heterogeneity and variability of an in vivo biofilm, allowing for the analysis of both biofilm and tooth. ${ }^{28}$ The microcosm biofilm model is able to produce reproducible biofilms that are representative 


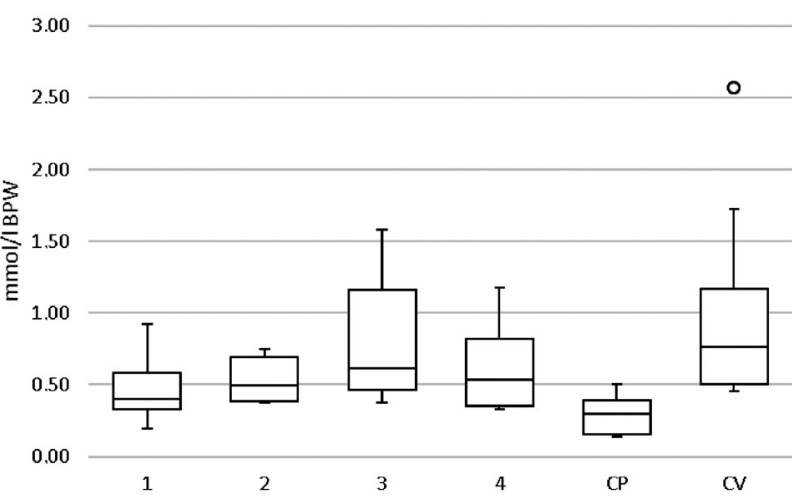

1-2: M. urundeuva at 1000 and $0.1 \mu \mathrm{g} / \mathrm{mL}$, respectively; 3-4: $Q$. grandiflora at 1000 and $0.1 \mu \mathrm{g} / \mathrm{mL}$, respectively; PC: Positive control (chlorhexidine, PerioGard ${ }^{\circledR}$ ); VC: Vehicle (negative) control; ': Outliers. (Kruskal-Wallis/Dunn, $p=0.0121$ )

Figure 3- Boxplot of the lactic acid production (mmol/L BPW) using lactic dehydrogenase method of oral microbia ( $60 \%$ of the species from the original inoculum are preserved), ${ }^{29}$ however, it does not allow for checking the effect of antimicrobial agents on specific microorganisms. Furthermore, the continuous sugar exposure during 14 days produced a very aggressive biofilm inducing enamel cavitation, as can be seen in the TMR pictures (Figure 5).

M. urundeuva and $Q$. grandiflora were chosen as they are easily found in Brazilian Cerrado. The ethanolic extracts of $M$. urundeuva leaves and bark have as active components gallic acid, methyl gallate, ethyl gallate, chlorogenic and protocatechuic acid, saponins, flavonoids, tannins and polyphenols. ${ }^{30}$ The ethanolic extracts of $Q$. grandiflora leaves present gallic and ellagic acids derivatives, galotannins,

Table 2- Median (interquartile interval) of the soluble and insoluble EPS ( $\mu \mathrm{g} / \mathrm{mg}$ biofilm)

\begin{tabular}{lcc}
\hline \multicolumn{1}{c}{ Treatments } & Soluble EPS $(\mu \mathrm{g} / \mathrm{mg})$ & Insoluble EPS $(\boldsymbol{\mu g} / \mathbf{m g})$ \\
\hline $35 \%$ Alcohol (vehicle/negative control) & $0.22(0.06)^{\mathrm{b}}$ & $0.32(0.17)^{\mathrm{b}}$ \\
\hline Chlorhexidine (positive control) & $0.07(0.05)^{\mathrm{a}}$ & $0.35(0.19)^{\mathrm{ab}}$ \\
\hline M. urundeuva $1000 \mu \mathrm{g} / \mathrm{ml}$ & $0.15(0.10)^{\mathrm{ab}}$ & $0.45(0.28)^{\mathrm{ab}}$ \\
M. urundeuva $100 \mu \mathrm{g} / \mathrm{ml}$ & $0.22(0.16)^{\mathrm{ab}}$ & $0.79(0.65)^{\mathrm{ab}}$ \\
\hline M. urundeuva $10 \mu \mathrm{gl}$ & $0.12(0.04)^{\mathrm{ab}}$ & $0.38(0.24)^{\mathrm{ab}}$ \\
M. urundeuva $1.0 \mu \mathrm{g} / \mathrm{ml}$ & $0.14(0.07)^{\mathrm{ab}}$ & $0.59(0.28)^{\mathrm{ab}}$ \\
M. urundeuvaa $0.1 \mu \mathrm{g} / \mathrm{ml}$ & $0.25(0.15)^{\mathrm{b}}$ & $0.50(0.23)^{\mathrm{ab}}$ \\
Q. grandiflora $1000 \mu \mathrm{g} / \mathrm{ml}$ & $0.28(0.13)^{\mathrm{b}}$ & $0.87(0.44)^{\mathrm{a}}$ \\
Q. grandiflora $100 \mu \mathrm{g} / \mathrm{ml}$ & $0.16(0.06)^{\mathrm{ab}}$ & $0.52(0.19)^{\mathrm{ab}}$ \\
Q. grandiflora $10 \mu \mathrm{g} / \mathrm{ml}$ & $0.17(0.07)^{\mathrm{ab}}$ & $0.44(0.33)^{\mathrm{ab}}$ \\
Q. grandiflora $1.0 \mu \mathrm{g} / \mathrm{ml}$ & $0.14(0.08)^{\mathrm{ab}}$ & $0.52(0.21)^{\mathrm{ab}}$ \\
Q. grandiflora $0.1 \mu \mathrm{g} / \mathrm{ml}$ & $0.17(0.09)^{\mathrm{ab}}$ & $0.74(0.42)^{\mathrm{ab}}$ \\
\hline
\end{tabular}

${ }^{*}$ Different superscript letters at the same column show significant differences between treatments (Kruskal-Wallis/Dunn, $p<0.0001$ and $p=0.0082$, respectively)

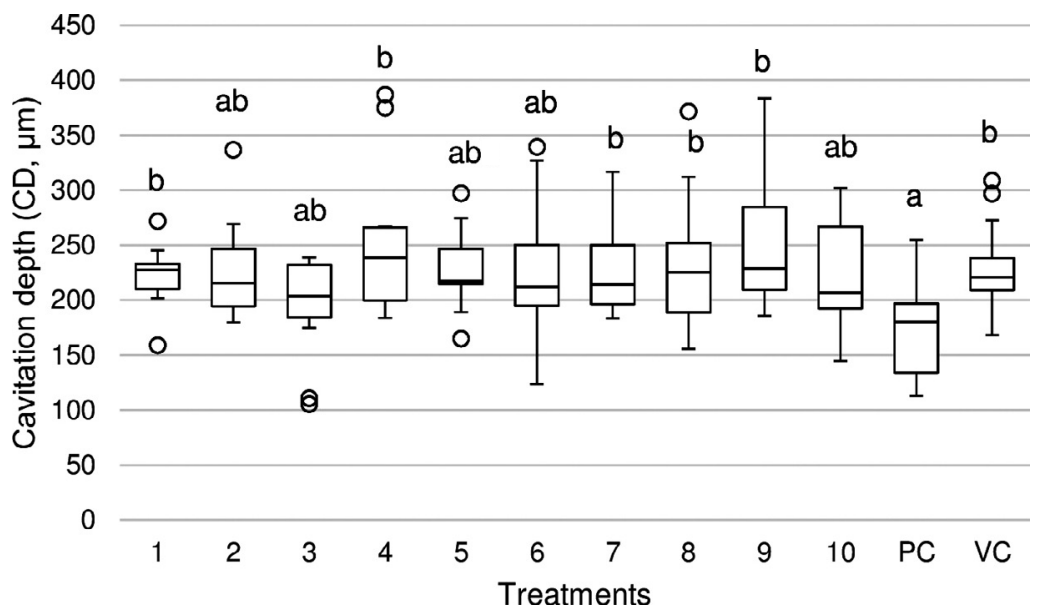

1- 5: M. urundeuva from 1000 to $0.1 \mu \mathrm{g} / \mathrm{mL}$ respectively; 6-10: Q. grandiflora from 1000 to $0.1 \mu \mathrm{g} / \mathrm{mL}$, respectively; PC: Positive control (chlorhexidine, PerioGard ${ }^{\circledR}$ ); VC: Vehicle (negative) control; ${ }^{\circ}$ : Outliers. Different letters show significant differences among the treatments (Kruskal-Wallis/Dunn, $p=0.0012$ )

Figure 4- Boxplot of the cavitation depth $(C D, \mu \mathrm{m})$ of the artificial enamel lesions created under microcosm biofilm model after applying the tested treatments 

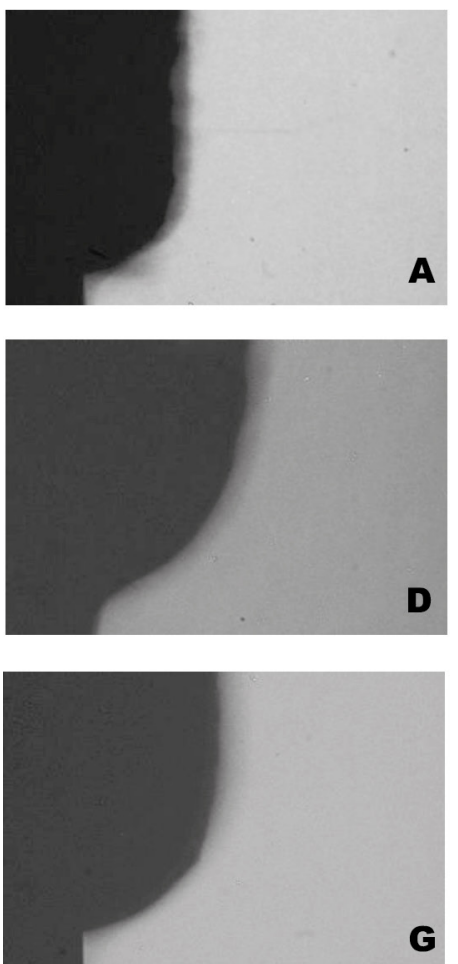

G

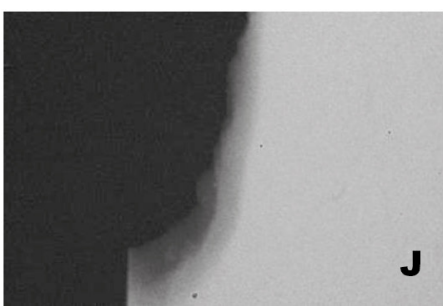

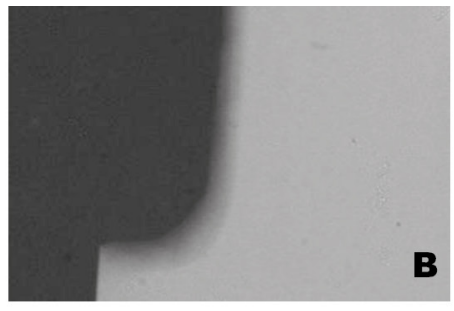

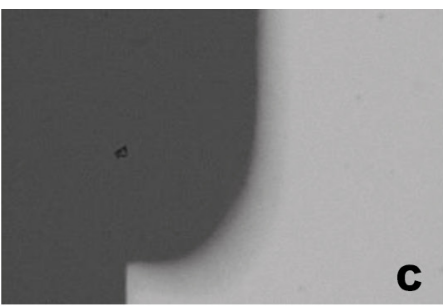

E
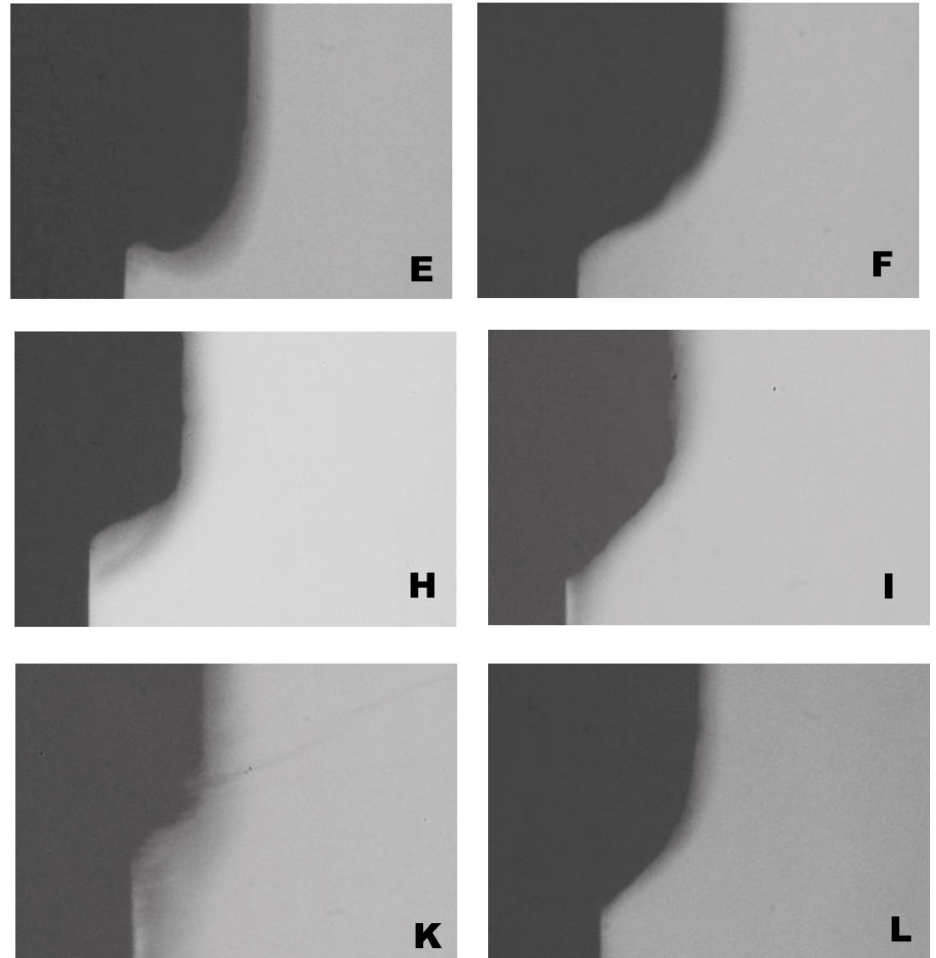

A-E) M. urundeuva from 1000 to $0.1 \mu \mathrm{g} / \mathrm{mL}$, respectively; F-J) Q. grandiflora from 1000 to $0.1 \mu \mathrm{g} / \mathrm{mL}$, respectively; K) Positive control (chlorhexidine, PerioGard ${ }^{\circledR}$ ); L) Vehicle (negative) control

Figure 5- Representative TMR pictures (20x) of artificial enamel lesions created using microcosm biofilm after applying the tested treatments

ellagitannins, triterpenes, flavonoids, benzoquinones and anthraquinones. ${ }^{31} \mathrm{~A}$ previous study showed that the main components of the $M$. urundeuva extract are flavonoids and tannins, ${ }^{20}$ which are related to its anti-inflammatory and antimicrobial properties. ${ }^{32,33}$

Generally, our study showed that $M$. urundeuva has superior antimicrobial effect compared to $Q$. grandiflora in agreement with a previous study, ${ }^{17}$ which might be due to its high content of tannins and polyphenols. Alves, et al. ${ }^{10}$ (2009) found Minimum Inhibitory Concentration and Minimum Inhibitory Adhesion Concentration values of $0.125 \mathrm{mg} / \mathrm{mL}$ and $0.0625 \mathrm{mg} /$ $\mathrm{mL}$ against mutans streptococci, respectively. Their MIC value is in agreement with our biofilm viability results, since we have seen antimicrobial effect with $0.1 \mathrm{mg} / \mathrm{mL}$ M. urundeuva. On the other hand, Pires, et al. ${ }^{17}$ (2018) showed antimicrobial effects at higher concentrations ( $M$. urundeuva $\geq 0.625 \mathrm{mg} / \mathrm{mL}$ and $Q$. grandiflora at $5 \mathrm{mg} / \mathrm{mL}$ ), which may be due to the biofilm model (3-days mutans streptococci biofilm) applied in their study.

With respect to $Q$. grandiflora, most studies have tested its effect on non-cariogenic bacteria such as Staphylococcus aureus, Escherichia coli, Bacillus cereus, Pseudomonas aeruginosa, Streptococcus pyogenes and Helicobacter pylori. ${ }^{15,34}$ The first study dealing with the anti-caries effect of $Q$. grandiflora was recently done by Pires, et al. ${ }^{17}$ (2018). Differently from our study, Pires, et al. ${ }^{17}$ (2018) only found antimicrobial effect of $Q$. grandiflora against mutans streptococci at $5 \mathrm{mg} / \mathrm{mL}$, which might be due to differences in the biofilm model between both studies (monospecies biofilm vs. microcosm biofilm) as discussed above.

Despite the extracts being able to reduce bacteria viability as well as the number of lactobacilli and mutans streptococci, they did not interfere in biofilm metabolism, and, therefore, they were unable to reduce caries lesions development, which corroborates 
with a previous study. ${ }^{17}$ Despite the treatments having reduced the number of viable bacteria, the microorganisms were still able to produce acid and EPS, which in turn induced enamel demineralization similar to the negative control. Our work provided support for the statement that not all antimicrobial agents have anti-caries potential. ${ }^{5}$ Furthermore, we could not find a dose-response with respect to viability and, therefore, the antimicrobial effect of natural agents might have their biological relevance questioned.

On the other hand, it is important to emphasize that other bacteria not analyzed in the present study could have contributed to enamel caries development (Scardovia wiggsiae, Bifidobacterium spp. and Actinomyces spp.), ${ }^{35}$ which shall be further confirmed under this model in future studies.

In disagreement, a previous study has shown that an aqueous solution of $M$. urundeuva protected against enamel surface cross-sectional hardness loss in Wistars rats inoculated with mutans streptococci, after 7 weeks of cariogenic challenges. ${ }^{16}$ The different result found in the cited study might be due to the greater concentration of the extract $(7.5 \mathrm{mg} / \mathrm{mL})$ as well as the type of extract (aqueous) applied by a previous study and to the low velocity of caries development in vivo. It is also important to consider that a hardness assay is unable to show if the cariogenic challenges induced tooth cavitation, ${ }^{36}$ which is considered a limitation of the method.

Further studies shall give attention to test the antimicrobial effect of $M$. urundeuva extracts, varying concentrations, solvents and vehicles, under microcosm biofilm or in situ model, to confirm the possible absence of anti-caries effect. Other important point to be considered in future studies is the analysis of the cytotoxic and biological effect of the plants extracts as well. ${ }^{20,33}$

\section{Conclusions}

The extracts showed antimicrobial effects (especially M. urundeuva) on the microcosm biofilm; however, no effect was observed on the biofilm metabolism and neither anti-caries effect under this biofilm model.

\section{Acknowledgements}

The authors thank CAPES for the concession of a scholarship to the first author. We also would like to thank FAPESP due to a grant provided to the last author (2017/00556-0). The funders had no role in study design, data collection and analysis, decision to publish, or preparation of the manuscript.

\section{Ethical approval \\ CEEA 43948115.2.0000.5417.}

\section{References}

1- Takahashi N, Nyvad B. The role of bacteria in the caries process: ecological perspectives. J Dent Res. 2011;90:294-303.

2- Marsh PD, Moter A, Devine DA. Dental plaque biofilms: communities, conflict control. Periodontol 2000. 2011;55(1):16-35.

3- Rugg-Gunn A. Dental caries: strategies to control this preventable disease. Acta Med Acad. 2013;42(2):117-30.

4- Braga AS, Pires JG, Magalhães AC. Commercial antimicrobials mouthrinses on caries and periodontitis-related biofilm control - a review of literature. Braz Dent Sci. 2017;20(3):13-23.

5- Braga AS, Pires JG, Magalhães AC. Effect of a mouthrinse containing Malva sylvestris on the viability and activity of microcosm biofilm and on enamel demineralization compared to known antimicrobials mouthrinses. Biofouling. 2018;34(3):252-61.

6- Henley-Smith CJ, Botha FS, Lall N. The use of plants against oral pathogens. In: Méndez-Vilas $A$, editor. Microbial pathogens and strategies for combating them: science, technology and education. Badajoz: Formatex Research Center; 2013. p. 1375-84.

7- Forzza RC, Baumgratz JF, Bicudo CE, Canhos DA, Carvalho AA Jr., Coelho MA, et al. New Brazilian floristic list highlights conservation challenges. BioScience. 2012;62(1):39-45.

8- Botelho MA, Rao VS, Carvalho CB, Bezerra-Filho JG, Fonseca $\mathrm{SG}$, Vale ML, et al. Lippia sidoides and Myracrodruon urundeuva gel prevents alveolar bone resorption in experimental periodontitis in rats. J Ethnopharmacol. 2007;113(3):471-8.

9- Montanari RM, Barbosa LC, Demuner AJ, Silva CJ, Andrade NJ, Ismail FM, et al. Exposure to Anacardiaceae volatile oils and their constituents induces lipid peroxidation within food-borne bacteria cells. Molecules. 2012;17(8):9728-40.

10- Alves P, Queiroz LMG, Pereira JV, Pereira MS. In vitro antimicrobial, antiadherent and antifungal activity of Brazilian medicinal plants on oral biofilm microorganisms and strains of the genus Candida. Rev Soc Bras Med Trop. 2009;42(2):222-4.

11- Carlini EA, Duarte-Almeida JM, Rodrigues E, Tabach R. Antiulcer effect of the pepper trees Schinus terebinthifolius Raddi (aroeira-dapraia) and Myracrodruon urundeuva Allemão, Anacardiaceae (aroeirado-sertão). Rev Bras Farmacogn. 2010;20(2):140-6.

12- Hiruma-Lima CA, Santos LC, Kushima $\mathrm{H}$, Pellizzon $\mathrm{CH}$, Silveira GG, Vasconcelos PC, et al. Qualea grandiflora, a Brazilian "Cerrado" medicinal plant presents an important antiulcer activity. J Ethnopharmacol. 2006;104(1-2):207-14.

13- Sousa CM, Silva HR, Vieira-Jr. GM, Ayres MC, Costa CL, Araújo DS, et al. Total phenolics and antioxidant activity of five medicinal plants. Quim Nova. 2007;30(2):351-5.

14- Gaspi FO, Foglio MA, Carvalho JE, Moreno RA. Pharmacological activities investigation of crude extracts and fractions from Qualea grandiflora Mart. J Ethnopharmacol. 2006;107(1):19-24.

15- Moura CO, Nascimento GP, Pinto CR. Atividade antibacteriana de Qualea grandiflora Mart. (Vochysiaceae). BioFar. 2012;8(2):34-42. 
16- Menezes TE, Delbem AC, Brighenti FL, Okamoto AC, Gaetti-Jardim E Jr. Protective efficacy of Psidium cattleianum and Myracrodruon urundeuva aqueous extracts against caries development in rats. Pharm Biol. 2010;48(3):300-5.

17- Pires JG, Zabini SS, Braga AS, Fabris RC, Andrade FB, Oliveira RC, et al. Hydroalcoholic extracts of Myracrodruon urundeuva All. and Qualea grandiflora Mart. leaves on Streptococcus mutans biofilm and tooth demineralization. Arch Oral Biol. 2018;91:17-22.

18- Marcenes W, Kassebaum NJ, Bernabé E, Flaxman A, Naghavi M, Lopez A, et al. Global burden of oral conditions in 1990-2010. J Dent Res. 2013;92(7):592-7.

19- Souza BM, Fernandes Neto C, Salomão PM, Vasconcelos LR, Andrade FB, Magalhães AC. Analysis of the antimicrobial and anticariogenic effect of $\mathrm{TiF}_{4}$ varnish under a microcosm biofilm formed on enamel. J Appl Oral Sci. 2018;26:e20170304.

20- Machado AC, Souza LP, Saldanha LL, Pieroni LG, Matos AA, Oliveira FA, et al. "Aroeira" (Myracrodruon urundeuva) methanol extract: the relationship between chemical compounds and cellular effects. Pharm Biol. 2016;54:2737-41.

21- McBain AJ. Chapter 4 In vitro biofilm models: an overview. Adv Appl Microbiol. 2009;69:99-132.

22- Zhang K, Cheng L, Wu EJ, Weir MD, Bai Y, Xu HH. Effect of waterageing on dentine bond strength and anti-biofilm activity of bonding agent containing new monomer dimethylaminododecyl methacrylate. J Dent. 2013;41(6):504-13.

23- Saravia ME, Nelson-Filho P, Ito IY, Silva LA, Silva RA, Emilson CG. Morphological differentiation between $S$. mutans and $S$. sobrinus on modified SB-20 culture medium. Microbiol Res. 2011;166(1):63-7.

24- Lima JP, Sampaio de Melo MA, Borges FM, Teixeira AH, SteinerOliveira $C$, Nobre dos Santos $M$, et al. Evaluation of the antimicrobial effect of photodynamic antimicrobial therapy in an in-situ model of dentine caries. Eur J Oral Sci. 2009;117(5):568-74.

25- Cheng L, Zhang K, Melo MA, Weir MD, Zhou X, Xu HH. Anti-biofilm dentin primer with quaternary ammonium and silver nanoparticles. J Dent Res. 2012;91(6):598-604.

26- Aires CP, Del Bel Cury, AA, Tenuta LMA, Klein MI, Koo H, Duarte S, et al. Effect of starch and sucrose on dental biofilm formation and on root dentine demineralization. Caries Res. 2008;42(5):380-6.
27- Zappi DC, Filardi FL, Leitman P, Souza VC, Walter BM, Pirani JR, et al. Growing knowledge: an overview of seed plant diversity in Brazil. Rodriguésia. 2015;66(4):1085-113.

28- Maske TT, Brauner KV, Nakanishi L, Arthur RA, van de Sande FH, Cenci MS. An in vitro dynamic microcosm biofilm model for caries lesion development and antimicrobial dose-response studies. Biofouling. 2016;32(3):339-48

29- Rudney JD, Chen R, Lenton P, Li J, Li Y, Jones RS, et al. A reproducible oral microcosm biofilm model for testing dental materials. J Appl Microbiol. 2012;113(6):1540-53.

30- Mota BC, Royo VA, Fonseca JM, Santos AC, Melo Junior AF, Menezes $\mathrm{EV}$, et al. Comparative studies between the chemical constituents and biological properties of the extracts from the leaves and barks of Myracrodruon urundeuva Fr. All. J Med Plants Res. 2015;9(6):159-68. 31- Ayres MC, Escórcio SP, Costa DA, Chaves MH. Chemical constituents from leaves of the Qualea grandiflora: attribution of the NMR data of two diastereoisomeric acylated flavonoid glycosids. Quim Nova. 2008;31(6):1481-4.

32- Lima MR, Ximenes EC, Luna JS, Sant'Ana AE. The antibiotic activity of some Brazilian medicinal plants. Rev Bras Farmacogn. 2006;16(3):300-6.

33- Bueno CR, Valentim D, Jardim Junior ÉG, Mancuso DN, SivieriAraujo G, Jacinto RC, et al. Tissue reaction to Aroeira (Myracrodruon urundeuva) extracts associated with microorganisms: an in vivo study. Braz Oral Res. 2018;32:e42.

34- Bonacorsi C, Fonseca LM, Raddi MSG, Kitagawa RR, Vilegas W. Comparison of Brazilian plants used to treat gastritis on the oxidative burst of Helicobacter pylori-stimulated neutrophil. Evid Based Complement Alternat Med. 2013;2013:851621.

35- Henne K, Gunesch AP, Walther C, Meyer-Lueckel H, Conrads G, Esteves-Oliveira $\mathrm{M}$. Analysis of bacterial activity in sound and cariogenic biofilm: a pilot in vivo study. Caries Res. 2016;50(5):480-8.

36- Magalhães AC, Moron BM, Comar LP, Wiegand A, Buchalla W, Buzalaf MA. Comparison of cross-sectional hardness and transverse microradiography of artificial carious enamel lesions induced by different demineralising solutions and gels. Caries Res. 2009;43(6):474-83. 